University of Nebraska - Lincoln

DigitalCommons@University of Nebraska - Lincoln

June 1983

\title{
RECIPROCAL RECURRENT SELECTION FOR 21-DAY LITTER WEIGHT OF CROSSBRED GILTS. I. SELECTION APPLIED AND GENETIC CHANGE IN REPRODUCTION OF CROSSBRED GILTS
}

L. D. Young

Oklahoma State University-Stillwater

I. T. Omtvedt

Oklahoma State University-Stillwater, iomtvedt1@unl.edu

J. A. Whatley Jr.

US Department of Agriculture, Clay Center, NE

R. K. Johnson

University of Nebraska-Lincoln, rjohnson5@unl.edu

Follow this and additional works at: https://digitalcommons.unl.edu/animalscifacpub

Part of the Animal Sciences Commons

Young, L. D.; Omtvedt, I. T.; Whatley, J. A. Jr.; and Johnson, R. K., "RECIPROCAL RECURRENT SELECTION FOR 21-DAY LITTER WEIGHT OF CROSSBRED GILTS. I. SELECTION APPLIED AND GENETIC CHANGE IN REPRODUCTION OF CROSSBRED GILTS" (1983). Faculty Papers and Publications in Animal Science. 30. https://digitalcommons.unl.edu/animalscifacpub/30

This Article is brought to you for free and open access by the Animal Science Department at DigitalCommons@University of Nebraska - Lincoln. It has been accepted for inclusion in Faculty Papers and Publications in Animal Science by an authorized administrator of DigitalCommons@University of Nebraska - Lincoln. 


\title{
RECIPROCAL RECURRENT SELECTION FOR 21-DAY LITTER WEIGHT OF CROSSBRED GILTS. I. SELECTION APPLIED AND GENETIC CHANGE IN REPRODUCTION OF CROSSBRED GILTS ${ }^{1}$
}

\author{
L. D. Young ${ }^{2}$, I. T. Omtvedt ${ }^{3}$, J. A. Whatley, Jr. ${ }^{4}$ and R. K. Johnson ${ }^{5}$ \\ US Department of Agriculture, Clay Center, NE 68933 \\ and \\ Oklahoma State University-Stillwater 74074
}

\begin{abstract}
Summary
Six cycles of reciprocal recurrent selection (RRS) between Line 8 (Duroc) and Line 9 (Beltsville No. 1) were completed at the Fort Reno Livestock Research Center, El Reno, Oklahoma. A randomly mated control line was maintained. Each cycle of selection required three seasons. Selection of purebred pigs (born in the second season) was based on the mean 21-d litter weight of their maternal and paternal half-sib crossbred gilts that were born in the first season and farrowed in the third season (XB21DLWT). On the average, 5.8 maternal and paternal half-sib gilts contributed to the mean XB21DLWT for each purebred individual. The average potential selection differential for XB21DLWT was $5.64 \mathrm{~kg}$, but only $70.2 \%$ of this value was realized in the initial selection $(3.95 \mathrm{~kg})$. Disease problems and unsoundness were the primary reasons for this discrepancy. The potential, initial, final and weighted final standardized selection differentials for females averaged $61,60,55$ and $47 \%$, respectively, of the corresponding differentials for males. Standardized selection differentials were similar for Line 8 and Line 9. The estimate of realized heritability for XB21DLWT was $.076 \pm .319$ for the average of $8 \times 9$ and $9 \times 8$ gilts. Environ-
\end{abstract}

\footnotetext{
'Journal Article 4277, Oklahoma Agr. Exp. Sta., Stillwater.

${ }^{2}$ Roman L. Hruska U.S. Meat Animal Research Center, ARS, USDA, Clay Center, NE.

${ }^{3}$ Present address: Agr. Exp. Sta., Univ. of Nebraska, Lincoln 68583.

${ }^{4}$ Agr. Exp. Sta., Oklahoma State Univ., Stillwater 74074.

${ }^{5}$ Present address: Dept. of Anim. Sci., Univ. of Nebraska, Lincoln 68583.

Received December 16, 1982.

Accepted May 3, 1983.
}

mental trends, estimated from control data, were not significant for any of the traits evaluated. The genetic change in reproductive ability of $8 \times 9,9 \times 8$ and their unweighted average was estimated by regressing the deviation of the line mean from the control mean on generation number. In general, estimates of genetic change for litter size, litter weight and average pig weight/litter at 0,21 and $42 \mathrm{~d}$ of age were not significant, but all estimates were favorable. The estimated genetic change for 21-d litter weight was $1.04 \pm 1.25 \mathrm{~kg} /$ cycle of selection. Based on these results and considering the complexity of RRS, the increase in generation interval and the expected decline in purebred performance that theoretically should accompany successful RRS, it seems doubtful that RRS can be more beneficial than selection based on purebred performance as a method to improve productivity of crossbred gilts.

(Key Words: Reciprocal Recurrent Selection, Swine, Litter Weight.)

\section{Introduction}

Most market hogs are crossbreds and the primary criterion of genetic value in the purebreds should be the performance of their crossbred offspring rather than the performance of the purebreds themselves. Therefore, an important issue is whether selection within purebreds should be based upon crossbred progeny performance or upon purebred performance. The answer hinges partially upon the nature of the genetic mechanism of heterosis for the traits under consideration. If nonadditive gene effects other than simple dominance are important, a higher level of crossbred performance should be attainable through selection for combining ability (i.e., crossbred performance) than by selecting for purebred performance. In 
the absence of such gene effects, the same level of crossbred performance should be attainable by either selection procedure, but it may be attained faster by selecting for purebred performance (Comstock, 1960).

Comstock et al. (1949) proposed reciprocal recurrent selection (RRS) as a method of selecting for both general and specific combining ability of corn. This approach seemed applicable to swine and, consequently, selection experiments were initiated within the Regional Swine Breeding Laboratory to evaluate the effectiveness of RRS. Results have been published on experiments conducted at USDA, Miles City, Montana (Krehbeil et al., 1971a,b; Dickerson et al., 1974), Wisconsin (Biswas et al., 1971), Minnesota (Wong et al., 1971; Rempel, 1974) and USDA, Beltsville, Maryland (Hetzer et al., 1977; Bereskin and Hetzer, 1981). In all of these experiments, the effectiveness of RRS was compared with the effectiveness of selection based on purebred performance for various indices combining preweaning and postweaning information.

The purpose of this paper is to present the direct and correlated responses for reproductive traits of crossbred gilts from the RRS experiment conducted at Oklahoma. Selection was based on mean $21-d$ litter weight production of maternal and paternal crossbred half-sib gilts (XB21DLWT).

\section{Experimental Procedure}

Experimental Design. The experiment was conducted at the Fort Reno Livestock Research Station, El Reno, Oklahoma from 1960 through 1970. Two select lines and a control line were maintained. Six cycles of RRS between Line 8 (Duroc) and Line 9 (Beltsville No. 1) were completed.

The Line 8 foundation stock was an inbred Duroc line developed at $\mathrm{Ft}$. Reno with the exception of three gilts introduced in the first season from another inbred Duroc line developed at the Stillwater Station. The Line 9 foundation stock consisted of four sows and two boars purchased in 1949 from the LandracePoland China line developed at USDA, Beltsville, Maryland. Four additional boars of $50 \%$ Landrace and $50 \%$ Poland China breeding were introduced before 1957. All of the line 9 females were descendants of three of the foundation sows. The mean level of inbreeding during this study was approximately 10 and $16 \%$ for Line 8 and Line 9 , respectively.

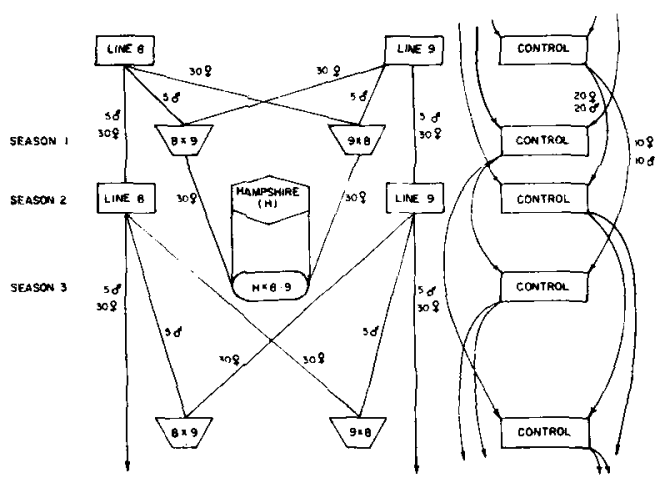

Figure 1. Reciprocal recurrent selection mating scheme.

The control line was established in 1958, with foundation females produced by mating Hampshire boars to $8 \times 9$ and $9 \times 8$ crossbred gilts. Hampshire boars and Duroc and Beltsville No. 1 boars, unrelated to Line 8 and Line 9 , were mated in a three-breed rotation to the foundation gilts. Landrace boars were used in place of Beltsville No. 1 boars after the first year because of difficulties in obtaining Beltsville No. 1 boars unrelated to Line 9. A new boar of each breed was purchased each season and two boars of each breed were in service each season. Three $8 \times 9$ and five $9 \times 8$ boars, born in the fall of 1960 in this experiment, were mated to control gilts to produce control litters in the fall of 1961. Thereafter, all male and female replacements came from within the line.

The mating scheme is illustrated in figure 1. The experiment was initiated with the 1960 fall farrowing season. Each cycle of selection required three seasons. In the first season, approximately five boars and 30 gilts of each line were reciprocally crossed to obtain crossbred gilts for production testing. In the second season (6 mo later), the individuals in each line were mated within line for line propagation. Mating was at random with the exception of avoiding matings of full-sibs and half-sibs. In the third season, approximately 30 gilts of each reciprocal cross were mated to Hampshire boars to evaluate crossbred female reproduction. Efforts were made to retain at least one crossbred gilt from each litter. If additional gilts were needed, they were chosen to equalize number/sire and number of each reciprocal cross as far as possible. The cycle was repeated with purebred pigs selected from the second farrowing. Purebred pigs were chosen randomly 
to be parents of crossbred litters born in the fall of 1960 and of purebred litters born in the spring of 1961. Thereafter, selection of purebred pigs was based on mean 21-d litter weight of their maternal and paternal half-sib crossbred gilts that farrowed in the third season. Each maternal and paternal crossbred half-sib record received equal weight. On the average, 5.8 (range $=2$ to 13 ) maternal and paternal half-sibs contributed to the mean XB21DLWT for each purebred individual. Individuals were not selected if they were deemed reproductively unsound or had visible signs of rhinitis. The plan was to select five males and 30 females within each purebred line each cycle. It was intended that one male and no more than three females be chosen from a given purebred litter. Exceptions to this plan will be noted in subsequent sections.

After the fall of 1961, approximately 30 control litters were farrowed each season. Of these 30 litters, about 20 were farrowed by gilts and about 10 were farrowed by second litter sows that had a litter the previous season by the same boar. Gilts retained for a second litter were selected randomly. No females produced more than two litters. Two boars of average weight at $21 \mathrm{~d}$ of age and two gilts of average weight at weaning ( $42 \mathrm{~d}$ of age) were chosen from each litter as potential replacements. The boar and gilt from each pair that were nearest the average of the entire group for rate of gain and probe backfat were retained for breeding, provided they were reproductively sound. Final selections were made with special emphasis on obtaining selection differentials as near zero as possible for growth rate and probe backfat. Equal numbers of boars and gilts were retained for breeding. No attention was given to $21-\mathrm{d}$ litter weight when selecting replacements. On the average, $76 \%$ of the litters born in a season contributed at least one boar or gilt to the next generation. Thus, very little selection pressure (intentional or unintentional) could be applied to any litter traits, especially when considering the above restrictions. To minimize inbreeding, each boar was mated at random to one gilt and no matings were permitted where a common ancestor appeared in the previous two generations of the pedigree.

All gilts farrowed their first litter at approximately $1 \mathrm{yr}$ of age and sows farrowed their second litter at about 18 mo of age. Spring litters were farrowed during February and March and fall litters were farrowed during
August and September. Individual pig weights were obtained at 0,21 and $42 \mathrm{~d}$ of age. Pigs were raised in confinement from birth to market weight and were self fed during the postweaning period. Pigs were removed from test at weekly intervals as they reached approximately $90.7 \mathrm{~kg}$.

Age of Dam Adjustments. Because all crossbred females only farrowed as gilts, sow data in the control line were adjusted to a gilt equivalent. This allowed all control line data to be used for estimating environmental effects. All 21 seasons of control line data were analyzed by least-squares procedures with a model that included the effects of year, season (spring or fall), age of dam and all two-way interactions and the three-way interaction. The three-way interaction was significant for litter size and average pig weight at 0,21 and $42 \mathrm{~d}$. Therefore, control line sow data were adjusted to a gilt equivalent basis by subtracting the observed mean difference between sow and gilt records from sow records within each season. The adjustments are shown in table 1 for the seven seasons when two-way cross gilts produced three-way cross litters. Adjustment factors were not calculated for litter weight. The components of litter weight (litter size and average pig weight) were adjusted and multiplied together to calculate an age-of-dam adjusted litter weight. The exceptionally large age of dam adjustment for litter size in the fall of 1964 may have been due to severe heat stress during the summer, affecting gilts to a greater degree than sows.

Inbreeding Adjustments. Direct response to selection was measured as reproduction of twoway cross gilts $(8 \times 9$ and $9 \times 8$ ) mated to Hampshire boars and is free of inbreeding effects. However, the control line did accumulate inbreeding (approximately .5\%/cycle). Similarly, evaluation of correlated genetic changes in Line 8, Line 9 and their two-way crosses (to be discussed in a subsequent paper) would be confounded with differential changes in level of inbreeding of dam and litter relative to the control line. Because changes in level of inbreeding were confounded with response to selection, adjustment for inbreeding effects was necessary in order to estimate response to selection and correlated genetic changes in other traits.

The effects of inbreeding of dam and litter (or individual) on preweaning litter and pig traits were investigated by analyzing the seven 
TABLE 1. NUMBER OF CONTROL GILT AND SOW LITTERS AND FACTORS TO ADJUST SOW LITTER SIZE AND AVERAGE PIG WEIGHT PER LITTER AT 0, 21 AND 42 DAYS TO A GILT EQUIVALENT

\begin{tabular}{|c|c|c|c|c|c|c|c|c|}
\hline \multirow[b]{4}{*}{ Farrowing season } & & & \multicolumn{6}{|c|}{ Adjustment factors for } \\
\hline & \multirow{2}{*}{\multicolumn{2}{|c|}{ Number }} & \multicolumn{3}{|c|}{ Litter size } & \multicolumn{3}{|c|}{ Avg pig weight $(\mathrm{kg})$} \\
\hline & & & & & & & & \\
\hline & Gilt & Sow & 0 & 21 & 42 & 0 & 21 & 42 \\
\hline $\begin{array}{l}1961 \text { fall } \\
1963 \text { spring } \\
1964 \text { fall } \\
1966 \text { spring } \\
1967 \text { fall } \\
1969 \text { spring } \\
1970 \text { fall }\end{array}$ & $\begin{array}{l}11 \\
12 \\
16 \\
21 \\
12 \\
20 \\
18\end{array}$ & $\begin{array}{r}0 \\
12 \\
5 \\
9 \\
11 \\
9 \\
10\end{array}$ & $\begin{array}{r}+.25 \\
-7.51 \\
-1.02 \\
-1.94 \\
-3.20 \\
-.39\end{array}$ & $\begin{array}{r}+.58 \\
-6.58 \\
-2.21 \\
-.87 \\
-2.37 \\
+.27\end{array}$ & $\begin{array}{r}+.33 \\
-6.71 \\
-2.25 \\
-.78 \\
-2.31 \\
+.13\end{array}$ & $\begin{array}{r}-.05 \\
.00 \\
-.14 \\
-.11 \\
-.06 \\
-.05\end{array}$ & $\begin{array}{l}-.99 \\
+.75 \\
-.52 \\
-.28 \\
-.80 \\
-.52\end{array}$ & $\begin{array}{r}-2.67 \\
+1.15 \\
-1.41 \\
-1.48 \\
-1.62 \\
-.86\end{array}$ \\
\hline
\end{tabular}

seasons of data on contemporary performance of straightbred Line 8 , Line 9 and control line sow litters. The estimated effects of inbreeding were not consistent for the same traits measured at different ages (e.g., pig weight at 0 , 21 and $42 \mathrm{~d}$ of age) and were not in agreement with literature estimates. Therefore, it seemed appropriate to use the method described by Krehbiel et al. (1971a) and used by Hetzer et al. (1977) to establish adjustments for inbreeding. The procedure involved using the weighted mean inbreeding effects from three experiments (Dickerson et al., 1954; Bereskin et al., 1968, 1969), calculated as percentage of the mean and multiplied by the means of the present study. The changes in performance from a $10 \%$ increase in inbreeding of the litter (or individual) were $-.06,-.31$ and -.39 pigs for litter size at 0,21 and $42 \mathrm{~d}$ of age, respectively, and .00 , -.04 and $-.27 \mathrm{~kg}$ for average pig weight at 0 , 21 and $42 \mathrm{~d}$ of age, respectively. The corresponding changes from a $10 \%$ increase in inbreeding of dam were $-.31,-.35$ and -.33 pigs and $-.01,-.08$ and $-.15 \mathrm{~kg}$. These adjustments were used throughout the study. All control line data were adjusted to zero inbreeding of dam and litter.

Selection Differentials. Selection differentials were calculated from unadjusted data that were the bases for selection. Selection differen. tials were calculated only for the trait of selection: mean 21-d litter weight of maternal and paternal crossbred half-sibs (XB21DLWT). Initial selection differentials were computed for each breed and sex subclass, giving equal weight to each individual producing a two-way cross litter. The mean performance of the selected individuals was deviated from the appropriate breed and sex subclass mean. Maximum potential selection differentials were calculated assuming that selection procedures were strictly followed. The same number of individuals were chosen as were included in calculating the initial selection differentials. Individuals were ranked on XB21DLWT, and one male and a maximum of three females were chosen from the highest ranking litters. Final selection differentials gave equal weight to each individual that had at least one crossbred daughter producing a three-way cross litter. Weighted final selection differentials were computed by weighting the selection differential of each individual by the number of crossbred daughters producing three-way cross litters. Standardized selection differentials were computed by dividing the selection differential for each breed and sex subclass by the corresponding standard deviation.

Three Line 8 males, four Line 9 males and three Line 9 females were introduced into the corresponding select lines during the experiment (table 2). The selection differential of these animals was assumed to be zero.

Statistical Analysis. After adjusting control line data to a gilt basis and zero inbreeding of dam and litter, data were analyzed by leastsquares procedures (Harvey, 1975) to estimate season-line means. The model included effects of line, season and season $x$ line. The linear and quadratic effects of day born within a season were also included and were fitted within season (subclass regression). 


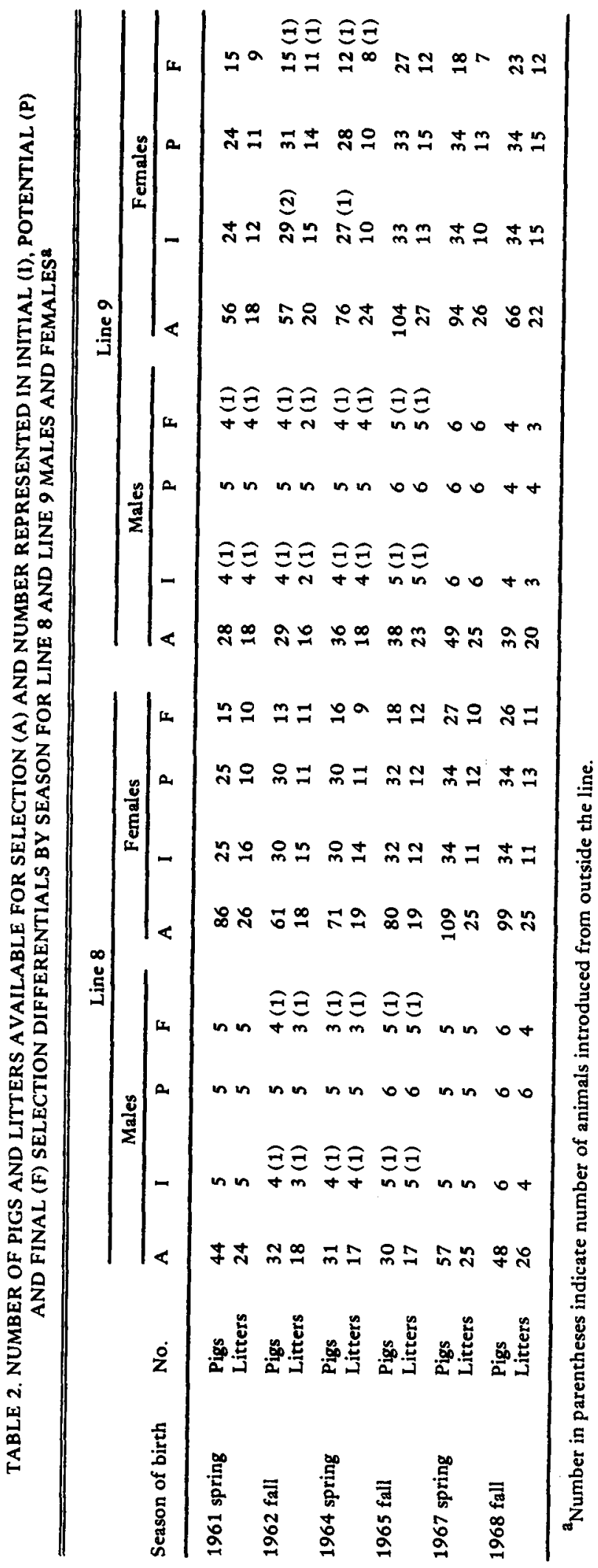


No genetic change was assumed to occur in the control line; therefore, the regression of control line means on cycle of selection estimated the environmental trend.

Genetic change per cycle of selection was calculated for $8 \times 9,9 \times 8$ gilts and their unweighted average $(\overline{8998})$. The genetic change was estimated by regressing the deviation of line means on cycle of selection.

Realized heritability of XB21DLWT was estimated by regressing response on cumulative weighted final selection differential.

Standard errors of the estimates of environmental and genetic change and estimates of realized heritability were adjusted for genetic drift variance according to procedures outlined by Dickerson (1969) and Hill (1972), respectively. Genetic drift variance was estimated in each population by dividing additive genetic variance by the effective population size (Dickerson, 1969; Hill, 1976). Additive genetic variance was estimated by multiplying an average literature heritability estimate (Young et al., 1978) times the residual mean square resulting from the above least-squares analysis for each trait.

\section{Results and Discussion}

Selection Applied. The six seasons during which selection was practiced among purebreds are shown in table 2 . The number of individuals and number of litters represented for number available for selection, number necessary to achieve maximum potential selection differentials, number selected and the number initially selected that had reproducing crossbred daughters (final) are also shown for each breed, sex and season subclass. As expected, fewer females and litters were represented in the final selection differentials than in the initial selection differentials. The main cause was failure of some purebred gilts to produce crossbred gilts or the failure of their crossbred daughters to conceive. This illustrates one of the difficulties of RRS selection as pointed out by Comstock (1961). One must obtain purebred and crossbred progeny from each individual. When reproductive problems lead to a lack of one kind of progeny, the other kind of progeny are of little use. This is particularly true if sires are lost.

By definition, potential number of individuals was the same as the number initially selected. Potential number of litters was calculated assuming that selection procedures were strictly followed. Even when number of potential and number of initial litters agreed, it did not necessarily mean that the same litters were represented in both cases. The disagreement between potential number of litters and initial number of litters for males resulted from selecting two males from some litters. This occurred in Line 8 and Line 9 males in the fall of 1962 and 1968.

In five out of 12 cases, the same number of females could have been obtained from fewer litters than actually were sampled if selection procedures had been followed strictly. In the spring of 1967 and fall of 1968, fewer litters were sampled to obtain Line 8 females than projected by following selection guidelines. In these cases, more than three gilts were chosen from some litters. The same was true for Line 9 females in the fall of 1965 and in the spring of 1967.

The standardized initial, maximum potential, final and weighted final selection differentials are presented in table 3 . The average standardized potential selection differential for XB21DLWT was .95 standard units $(5.64 \mathrm{~kg})$, but only $68 \%$ of this value was realized in the initial selection (.65 standard units, $3.96 \mathrm{~kg}$ ). Part of this loss, particularly in males, resulted from the zero selection differential of introduced animals. However, the main loss of potential selection differential occurred in the first season. In the spring of 1961 the standardized initial selection differential for Line 9 was -.13 compared with a standardized potential selection differential of .82 . In the spring of 1961 the initial selection differential in Line 8 represented only $23 \%$ of the potential. The primary reason the initial selection differential did not achieve a higher percentage of the potential selection differential was the avoidance of individuals that were unsound or exhibited visible signs of rhinitis. This was particularly true during the first season of selection. The initial selection differentials for Line 9 males selected in the fall of 1962 and Line 8 males selected in the fall of 1968 were greater than the potential selection differentials. This resulted from selecting two males, instead of the intended one, from the highest ranking litters. The initial selection differential for Line 8 females selected in the fall of 1968 was also greater than the corresponding potential selection differential because more than three gilts were chosen from the higher ranking litters. Overall, final and weighted final selection 


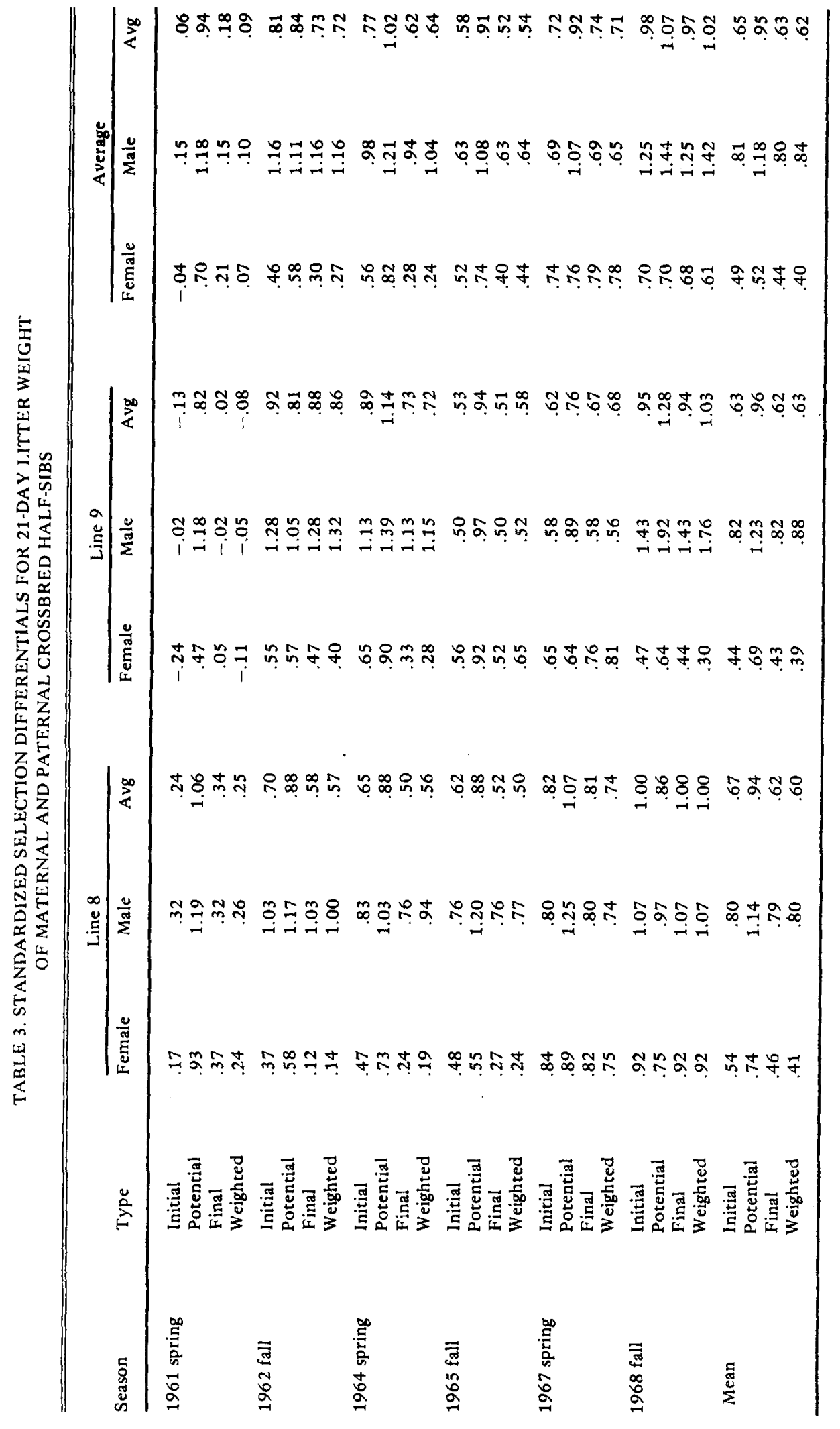


differentials differed only slightly from initial selection differentials. Thus, after initial selection, there appeared to be little additional natural or artificial selection for or against XB21DLWT.

The standardized potential, initial, final and weighted final selection differentials for females averaged $61,60,55$ and $47 \%$, respectively, of the corresponding selection differentials of males. When averaged over line and sex, the average standardized selection differentials were fairly consistent from season to season with the exception of those from the spring of 1961. When averaged over sex and season, the standardized potential selection differentials were nearly equal for Line 8 and Line 9 (.94 vs .96). The lines were also very similar in initial $(.67 \mathrm{vs}$ .63 ), final (.62 vs .62) and weighted final (.60 vs .63) selection differentials.

Season-Line Means. The number of litters produced by each breed type of gilt, for each season in which response was measured, is shown in table 4. Data for litter size and litter weight at all ages included records from all females farrowing, even if all pigs were dead at 21 or $42 \mathrm{~d}$. When analyzing average pig weight/ litter, records with no pigs at 21 and $42 \mathrm{~d}$ were deleted. This resulted in deleting only one record for each breed type of gilt over the seven seasons.

The least-squares means for reproductive performance of $8 \times 9,9 \times 8$ and control gilts adjusted for age of dam, inbreeding of dam, inbreeding of litter and day of birth are presented in tables 5,6 and 7. The average of $8 \times 9$ and $9 \times 8$ breed type means is denoted as $\overline{8998}$

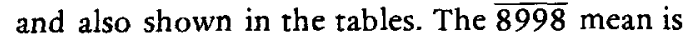

TABLE 4. NUMBER OF LITTER RECORDS BY BREED TYPE OF GILT AND SEASON

\begin{tabular}{llll}
\hline & \multicolumn{3}{c}{ Breed group of gilt } \\
\cline { 2 - 4 } Season & Control & $8 \times 9$ & $9 \times 8$ \\
\hline 1961 fall & 11 & 26 & 10 \\
1963 spring & 24 & 22 & 25 \\
1964 fall & $21^{\mathrm{a}}$ & 19 & $17^{\mathrm{a}}$ \\
1966 spring & 30 & 24 & 34 \\
1967 fall & 23 & $33^{\mathrm{a}}$ & 29 \\
1969 spring & 29 & 22 & 31 \\
1970 fall & 28 & 37 & 26 \\
\hline
\end{tabular}

${ }^{a}$ Number of records for average pig weight at 21 and $42 \mathrm{~d}$ was one less than the number shown.

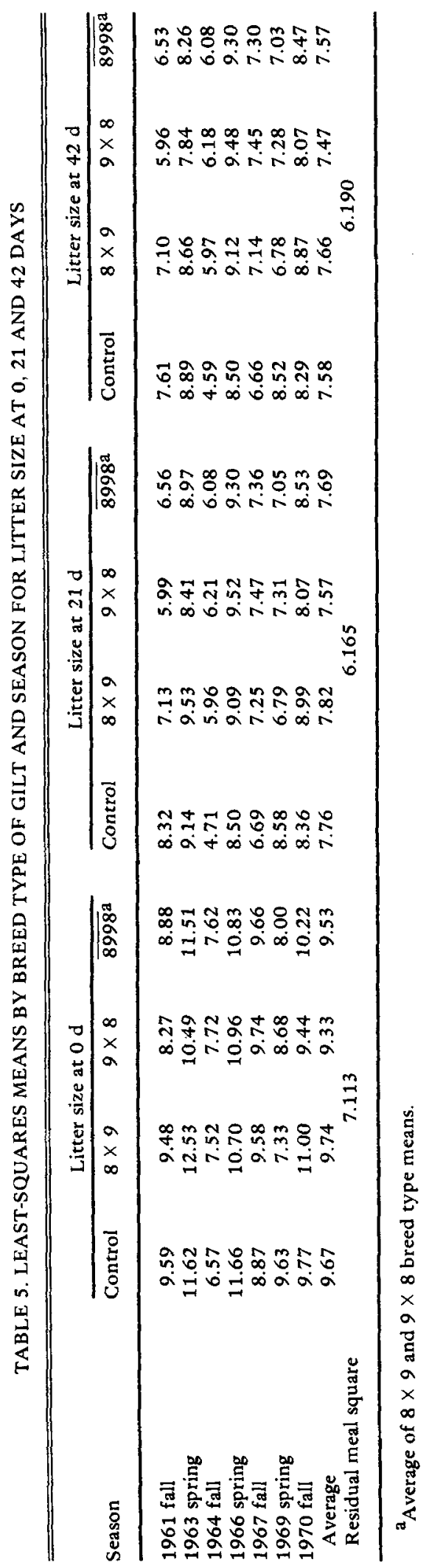


most important because selection was based on reproduction of both types of reciprocal cross gilts. The interaction of line with season was not significant for any litter traits. Averaged over all seasons, there were no significant differences among gilt breed types for litter size at 0,21 or $42 \mathrm{~d}$ of age. Crossbred gilts had significantly heavier average pig weight than did control gilts at 0,21 and $42 \mathrm{~d}$ of age. Consequently, crossbred gilts had heavier litters at 0 $(\mathrm{P}<.05), 21(\mathrm{P}<.05)$ and $42 \mathrm{~d}(\mathrm{P}<.10)$.

Crossbred gilts out of Line 9 dams had heavier average pig weight and heavier litter weight at 0,21 and $42 \mathrm{~d}$ than crossbred gilts out of Line 8 dams, although the difference for litter weight at $42 \mathrm{~d}$ was not significant.

Environmental Trend. There was no suggestion of a significant environmental trend for any trait. The environmental trend was $-.04 \pm$ $.36, .04 \pm .33$ and $.12 \pm .33$ pigs/cycle for litter size at 0,21 and $42 \mathrm{~d}$ of age, respectively; -.26 $\pm .45, .83 \pm 1.27$ and $2.90 \pm 3.37 \mathrm{~kg} /$ cycle for litrer weight at 0,21 and $42 \mathrm{~d}$ of age, respectively; and $-.02 \pm .02, .08 \pm .08$ and .14 $\pm .25 \mathrm{~kg} /$ cycle for average pig weight at 0,21 and $42 \mathrm{~d}$ of age, respectively.

The control line was started from a crossbred foundation and would be subject to heterosis and recombination loss (Dickerson, 1973), which should cause a decrease in reproduction. Apparently, these effects were not large or were overwhelmed by major environmental changes. In a previous analysis of 14 generations of this control line, Edwards et al. (1971) concluded that the population had remained genetically stable.

Genetic Cbange. The genetic trends were significantly positive for average pig weight at birth for $8 \times 9$ and $9 \times 8$ gilts and $\overline{8998}$ (table 8 ). Despite the negative estimate of genetic trend for litter size at birth in $8 \times 9$ gilts, the relatively large positive genetic trend in average pig weight resulted in a positive increase in litter birth weight that approached significance. In $9 \times 8$ gilts, the nonsignificant but relatively large genetic trend for litter size at birth, combined with a modest but significant increase in average birth weight, resulted in a nonsignificant positive genetic trend for litter birth weight similar in size to the corresponding genetic trend in $8 \times 9$ gilts. The genetic trend for litter weight at birth in $\overline{\mathbf{8 9 9 8}}$ was positive and approached significance because of a significant positive trend for average pig weight and despite an essentially zero trend (.01 $\mathrm{pig} / \mathrm{cycle}$ ) in litter size.

No other estimates of genetic trend approached significance. Genetic trends tended to be larger for litter size and smaller for average pig weight at all ages for $9 \times 8$ than for $8 \times 9$ gilts. The regressions for $\overline{8998}$ were in the desired direction and of reasonable magnitude. The genetic trend for litter 21-d weight of $\overline{\mathbf{8 9 9 8}}$, the trait under selection, was $1.04 \pm 1.25$ $\mathrm{kg} / \mathrm{cycle}$.

Realized Heritability. Realized heritability of XB21DLWT was estimated as the regression of response on cumulative weighted final selection differential. This estimate is roughly equivalent to realized heritability of a half-sib family mean, which is represented by the formula

$$
\frac{1 / 4 n h^{2}}{1+(n-1) t}
$$

where $\mathrm{n}$ is the number of individuals in the family, $h^{2}$ is the heritability of the trait measured on the individual and $t$ is the correlation of phenotypic values of members of the family. In this study, $h^{2}$ is the heritability of $21-d$ litter weight of a crossbred gilt, which differs somewhat from the normal interpretation of $h^{2}$ in a purebred population. The numerator of the $h^{2}$ estimated from crossbred progeny is not an unbiased estimate of additive genetic variance in the crossbred population because level of dominance and gene frequency differences between the two populations will affect the estimate (Stuber and Cockerham, 1965). Also, the value of $t$ is not straightforward because both maternal and paternal half-sibs were included in the half-sib mean for XB21DLWT. On average, 1.2 maternal half-sibs and 4.6 paternal half-sibs were included in each mean; therefore, $t$ would be approximately equal to the phenotypic correlation among paternal half-sibs.

Response was estimated by deviating the 21-d litter weight of $8 \times 9,9 \times 8$ and $\overline{8998}$ gilts from the 21-d litter weight of contemporary control gilts. The regression of response of $\overline{8998}$ on the average of the cumulative weighted final selection differentials of Line 8 and Line 9 males and females was $.076 \pm .319$. The regression of response of $8 \times 9$ gilts on the average cumulative weighted final selection differentials of Line 8 males and Line 9 females was $.071 \pm$ .296. The corresponding regression for $9 \times 8$ gilts was $.048 \pm .394$. 

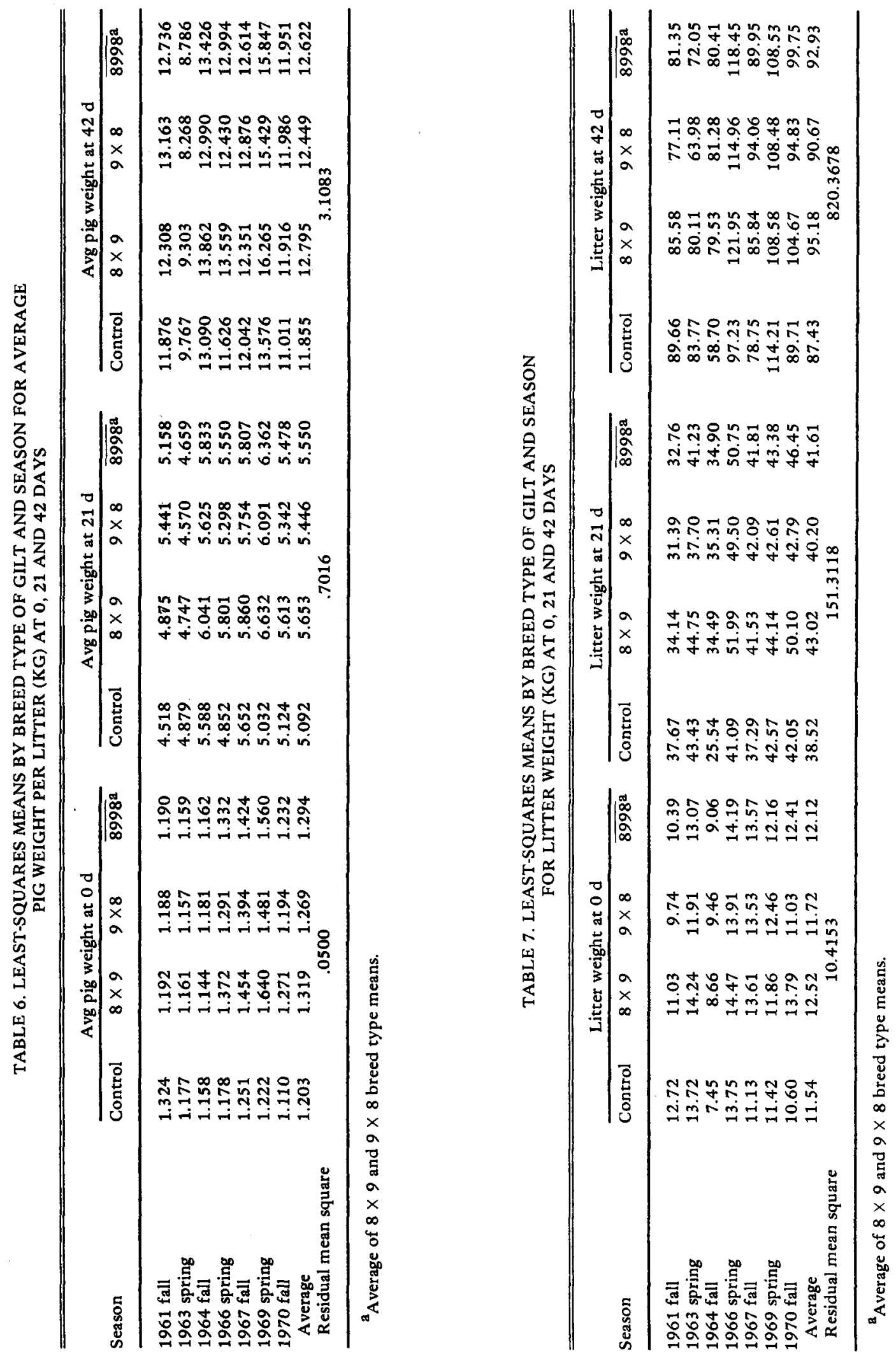
TABLE 8. REGRESSION OF DEVIATION OF LINE MEANS FROM CONTROL ON CYCLE OF SELECTION

\begin{tabular}{|c|c|c|c|}
\hline \multirow[b]{2}{*}{ Trait } & \multicolumn{3}{|c|}{ Breed type of gilt } \\
\hline & $8 \times 9$ & $9 \times 8$ & $\overline{8998^{a}}$ \\
\hline \multicolumn{4}{|c|}{ Litter size, pigs } \\
\hline Day 0 & $-.09 \pm .26$ & $.11 \pm .24$ & $.01 \pm .22$ \\
\hline 21 & $.02 \pm .26$ & $.15 \pm .32$ & $.08 \pm .27$ \\
\hline 42 & $-.02 \pm .26$ & $.11 \pm .29$ & $.04 \pm .25$ \\
\hline \multicolumn{4}{|c|}{ Average pig weight, kg } \\
\hline day 0 & $.07 \pm .03$ & $.04 \pm .02$ & $.06 \pm .02$ \\
\hline 24 & $.13 \pm .11$ & $.02 \pm .11$ & $.08 \pm .11$ \\
\hline 42 & $.26 \pm .22$ & $.24 \pm .23$ & $.25 \pm .19$ \\
\hline \multicolumn{4}{|c|}{ Litter weight, $\mathbf{k g}$} \\
\hline Day 0 & $.56 \pm .33$ & $.58 \pm .40$ & $.57 \pm .30$ \\
\hline 21 & $1.09 \pm 1.25$ & $.99 \pm 1.51$ & $1.04 \pm 1.25$ \\
\hline 42 & $1.40 \pm 3.23$ & $2.64 \pm 3.74$ & $2.02 \pm 3.18$ \\
\hline
\end{tabular}

${ }^{\text {a }}$ Average of $8 \times 9$ and $9 \times 8$ breed type means.

These values are about one-half as large as the heritability estimates for litter weaning weight obtained by Blunn and Baker (1949), Urban et al. (1966), Fahmy and Bernard (1972), Dickerson et al. (1974) and Strang and Smith (1979), but are very similar to the estimate reported by Cummings et al. (1947). These latter estimates are based on weaning at 42 and $56 \mathrm{~d}$. Based on these literature estimates, it would appear that rate of improvement of 21-d litter weight of crossbred gilts would be just as rapid, if not more so, when selection is based on purebred performance rather than on crossbred performance. This assumes that purebred performance can be improved as much as the heritability indicates and that heterosis for reproduction in the crossbred gilt will at least not decrease at the higher level of purebred performance. Selection based on purebred performance would have the added advantage of shorter generation interval than possible with RRS ( 1 vs $1.5 \mathrm{yr}$ ) and probably a larger selection differential because selection would be based on individual observations rather than a family mean.

\section{Discussion}

To our knowledge, no other experiments have been reported on RRS solely for litter production of crossbred gilts. However, literature from other species and other types of RRS are pertinent.
In two separate experiments with Drosophila (Bell et al., 1955), three methods of selection to maximize heterosis were compared with conventional closed population selection based on individual and family merit. The three methods were: (1) recurrent selection to an inbred tester for specific combining ability, (2) reciprocal recurrent selection for specific combining ability and (3) inbreeding and hybridization. The results of the two experiments led to similar conclusions. For characters of medium to high heritability, the closed population method led to the highest rate of improvement. This conclusion was also true for lowly heritable traits during the early stages of selection. The latter situation would apply to this experiment.

Recurrent selection should be useful when applied to characters closely related to fitness that have little additive genetic variance. Bowman (1962) reported an experiment on selection for large litter size in mice. Selection was made between males within a closed, noninbred population on the basis of performance of their test cross progeny resulting from mating with inbred line females. Response to selection was observed, but was very comparable with the expected response calculated on the assumption that all the variance between sires in crossing performance was additive genetic variance. The conclusion was that recurrent selection was ineffective in exploiting specific combining ability and did not produce a hybrid with a 
performance more extreme than could be produced by individual closed population selection. This would agree with the conclusions of this experiment.

Vinson et al. (1969) compared predicted responses of three crossbred selection methods using estimates of genetic parameters for seven quantitative traits from two genetically diverse mouse populations and their reciprocal crosses. Reciprocal recurrent selection was vastly superior to selection on purebred performance (mass selection or half-sib family selection) for litter size at birth, but not for 12-d litter weight of standardized litters. The latter trait is similar to the trait selected for in our experiment.

The ratio of change in the genotypic mean of crossbreds from selection for specific combining ability to change in genorypic mean of crossbreds from intra-population selection (IS) can be estimated according to procedures outlined by Comstock (1961). Using parameters reported by Wong et al. (1971) and assuming equal standardized selection differentials for both types of selection, this value would be 1.22 for litter size born alive. However, this value should be reduced by one-third (to .81) when progress is measured in years because RRS selection would require at least 1.5 yr/generation. So on an equal time basis, IS selection would improve crossbred gilt productivity faster than RRS selection with regards to litter size born.

Based on the results of this experiment and the literature reviewed above, it would seem unlikely that RRS selection for reproductive performance of crossbred gilts would be any more effective than selection based on purebred performance; the only possible exception may be litter size at birth and evidence for that is not overwhelming. Also, increased litter size at birth is not very important unless it results in more pigs raised/litter. If one also considers the complexity of RRS, the increase in generation interval and the expected decline in purebred performance that accompanies successful RRS selection, it seems doubtful that RRS can be more beneficial than selection based on purebred performance as a method to improve crossbred productivity.

\section{Literature Cited}

Bell, A. E., C. H. Moore and D. C. Warren. 1955. The evaluation of new methods for the improvernent of quantitative characteristics. Cold Spr. Harb. Symp. Quant. Biol. 20:197.

Bereskin, B. and H. O. Hetzer. 1981. Reciprocal recurrent selection in swine: Postweaning growth. J. Anim. Sci. 53:1446.

Bereskin, B., C. E. Shelby and L. N. Hazel. 1969. Monte Carlo studies of selection and inbreeding in swine. I. Genetic and phenotypic trends. J. Anim. Sci. 29:678.

Bereskin, B., C. E. Shelby, K. E. Rowe, W. E. Urban, Jr., C. T. Blunn, A. B. Chapman, V. A. Garwood, L. N. Hazel, J. F. Lasley, W. T. Magee, J. W. McCarty and J. A. Whatley, Jr. 1968. Inbreeding and swine productivity traits. J. Anim. Sci. 27:339.

Biswas, D. K., A. B. Chapman, N. L. First and H. L. Self. 1971. Intrapopulation vs. reciprocal recurrent selection in swine. J. Anim. Sci. 32:840.

Blunn, C. T. and M. L. Baker. 1949. Heritability estimates of sow productivity and litter performance. J. Anim. Sci. 8:89.

Bowman, J. C. 1962. Recurrent selection. II. An experimental study in mice and Drosophila. Genetical Res. 3:333.

Comstock, R. E. 1960 . Problems and evidence in swine breeding. J. Anim. Sci. 19:75.

Comstock, R. E. 1961. Reciprocal recurrent selection (RRS) with reference to swine breeding. 24th Annu. Rep. Regional Swine Breeding Laboratory, Ames, IA.

Comstock, R. E., H. F. Robinson and P. H. Harvey. 1949. A breeding procedure designed to make maximum use of both general and specific combining ability. Agron. J. 41:360.

Cummings, J. N., L. M. Winters and H. A. Stewart. 1947. The heritability of some factors affecting productivity of brood sows. J. Anim. Sci, 6:297.

Dickerson, G. E. 1969. Techniques for Research in Quantitative Animal Genetics. In: Techniques and Procedures in Animal Science Research. $p$ 36. Amer, Soc. Anim. Sci., Champaign, IL.

Dickerson, G. E. 1973. Inbreeding and Heterosis in Animals. In: Proc. Anim. Breeding and Genetics Symp. in Honor of Dr. Jay L. Lush. p 54. Amer. Soc. of Anim. Sci., Champaign, IL.

Dickerson, G. E., C. T. Blunn, A. B. Chapman, R. M. Kotuman, J. L. Kinder, E. J. Warwick, J. A. Whatley, Jr., M. L. Baker, J. L. Lush and L. M. Winters. 1954. Evaluation of selection in developing inbred lines of swine. Missouri Agr. Exp. Sta. Res. Bull. 551 .

Dickerson, G. E., H. O. Hetzer, E. V. Krehbeil and A. E. Flower. 1974. Effectiveness of reciprocal selection for performance of crosses between Montana No. 1 and Yorkshire swine. III. Expected and actual response. J. Anim. Sci. 39:24.

Edwards, R. L., I. T. Omtvedt and J. A. Whatley. 1971. Genetic analysis of a swine control population. I. Population stability. J. Anim. Sci, 32:179.

Fahmy, M. H. and C. S. Bernard. 1972. Reproductive performance of gilts from lines selected for feed utilization and carcass score. Can. J. Anim. Sci. 52:267.

Harvey, W. R. 1975. Least-squares analysis of data with unequal subclass numbers. USDA, ARS H-4.

Hetzer, H. O., R. H. Miller and R. C. Kling. 1977. 
Effectiveness of reciprocal recurrent selection for improving preweaning performance in swine. J. Anim. Sci. 45:989.

Hill, W. G. 1972. Estimation of realized heritabilities from selection experiments. II. Selection in one direction. Biometrics 28:767.

Hill, W. G. 1976. Variation in response to selection. In: E. Pollack, O. Kempthorne and T. Bailey, Jr. (Ed.) Proc. Int. Conf, on Quantitative Genetics, Iowa State Univ. Press, Ames.

Krehbeil, E. V., H. O. Hetzer, A. E. Flower, G. E. Dickerson, W. R. Harvey and L. A. Swiger. 1971a. Effectiveness of reciprocal selection for performance of crosses between Montana No. 1 and Yorkshire swine. I. Preweaning traits. J. Anim. Sci. 32:191.

Krehbeil, E. V., H. O. Hetzer, A. E. Flower, G. E. Dickerson, W. R. Harvey and L. A. Swiger. 1971b. Effectiveness of reciprocal selection for performance of crosses between Montana No. 1 and Yorkshire swine. II. Postweaning traits. J. Anim. Sci. 32:211.

Rempel, W. E. 1974. Selection for crossbred perform- ance in pigs. Proc. World Congress on Genetics Applied to Livestock Production, Vol. 1. p 849. Editorial Garsi, Londres 17, Madrid-28, Spain. Strang, G. S. and C. Smith. 1979. A note on the heritability of litter traits in pigs. Anim. Prod. 28:403.

Stuber, C. W. and C. C. Cockerham. 1965. Genetic effects and variance in hybrid populations. Genetics 54:1279.

Urban, W. E., Jr., C. E. Shelby, A. B. Chapman, J. A. Whatley, Jr. and V. A. Garwood. 1966. Genetic and environmental aspects of litter size in swine. J. Anim. Sci. 25:1148.

Vinson, W. E., E. J. Eisen and O. W. Robison. 1969. Predicted response to selection for crossbred performance in mice. J. Anim. Sci. 28:725.

Wong, W. C., W. J. Boylan and W. E. Rempel. 1971. Purebred versus crossbred performance as a basis of selection in swine. J. Anim. Sci. 32:605.

Young, L. D., R. A. Pumfrey, P. J. Cunningham and D. R. Zimmerman. 1978. Heritabilities and genetic and phenotypic correlations for prebreeding traits, reproductive traits and principal components. J. Anim. Sci. 46:937. 